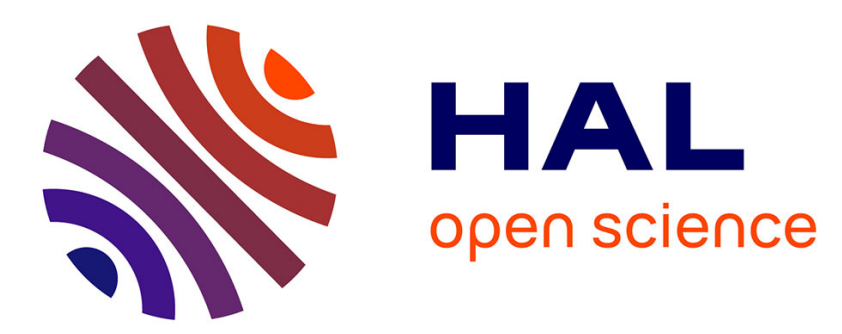

\title{
Does harvesting amplify environmentally induced population fluctuations over time in marine and terrestrial species?
}

\author{
Marlène Gamelon, Brett K Sandercock, Bernt-erik Sæther
}

\section{To cite this version:}

Marlène Gamelon, Brett K Sandercock, Bernt-erik Sæther. Does harvesting amplify environmentally induced population fluctuations over time in marine and terrestrial species?. Journal of Applied Ecology, 2019, 56 (9), pp.2186 - 2194. 10.1111/1365-2664.13466 . hal-03282120

\author{
HAL Id: hal-03282120 \\ https://hal.science/hal-03282120
}

Submitted on 8 Jul 2021

HAL is a multi-disciplinary open access archive for the deposit and dissemination of scientific research documents, whether they are published or not. The documents may come from teaching and research institutions in France or abroad, or from public or private research centers.
L'archive ouverte pluridisciplinaire HAL, est destinée au dépôt et à la diffusion de documents scientifiques de niveau recherche, publiés ou non, émanant des établissements d'enseignement et de recherche français ou étrangers, des laboratoires publics ou privés. 


\section{Does harvesting amplify environmentally induced population fluctuations}

2 over time in marine and terrestrial species?

4 Marlène Gamelon ${ }^{1, *}$, Brett K. Sandercock ${ }^{2}$ and Bernt-Erik Sæther ${ }^{1}$

$5 \quad{ }^{1}$ Centre for Biodiversity Dynamics, Department of Biology, Norwegian University of Science 6 and Technology, 7491 Trondheim, Norway.

$7 \quad{ }^{2}$ Department of Terrestrial Ecology, Norwegian Institute for Nature Research, 7485

8 Trondheim, Norway.

9

10

11

12

*Correspondence: marlene.gamelon@ntnu.no

\section{Abstract}

1. In marine and terrestrial ecosystems, organisms are affected by environmental variations that cause fluctuations in population size. The harvest-interaction hypothesis predicts that environmentally-induced fluctuations in population size are magnified by harvesting. Empirical evidence is urgently needed in the context of global change because greater fluctuations will increase extinction risk.

2. Here, we review theoretical and empirical work that has addressed the harvestinteraction hypothesis in fish, birds and mammals. We identify the mechanisms by which harvesting might make population size more variable over time and thereby increase the risk of extinction.

3. Theoretical models show that harvest can modify population structure in time and space, and that changes in the amplitude and synchrony of population dynamics both increase extinction risk. Empirical evidence indicates that fishing amplifies the effects of environmental changes on the population variability, but no empirical study of 
terrestrial species has tested for amplified environmentally-induced fluctuations due to hunting.

4. Synthesis and applications. In terrestrial species, theoretical studies have evaluated how environmentally-induced fluctuations in population size are magnified by different harvest strategies, but there is now an urgent need for an empirical evaluation of this hypothesis. Future research is needed to explore how hunting and climate interact and to test whether hunting enhances environmentally induced fluctuations in population numbers of terrestrial species.

34

35

KEYWORDS

36

climate change, environmental factors, fishing, hunting, population dynamics, harvesting, population size, environmentally induced fluctuations 


\section{1 | INTRODUCTION}

Free-ranging populations live in a global environment that is rapidly changing. All ecosystems, from marine to terrestrial, are impacted by global drivers of environmental change. Climate variation is one of the most important drivers of annual fluctuations in population size (Sæther 1997; Gaillard, Festa-Bianchet \& Yoccoz 1998; Sæther et al. 2016). Variability in climate may influence population size through changes in phenotypic traits such as body condition or key demographic rates including fecundity or survival (Jenouvrier 2013; Jenouvrier et al. 2018). For instance, climate variation impacts age of maturity, recruitment rates and hence the overall population dynamics of large herbivores (Sæther 1997; Post et al. 1999). Climate effects can have strong consequences on population persistence, because greater environmentally-induced fluctuations in population size will lead to higher extinction risk (Lande, Engen \& Saether 2003). Exploited natural populations are also affected by commercial, recreational or subsistence harvest, with removal of individuals through fishing or hunting. The magnitude of the fluctuations in population size can be large if declining populations are overharvested or populations that start to rebound have low harvest rates (Fryxell et al. 2010). To maintain sustainable harvest and to avoid extinction due to overexploitation in the current context of global change, it is crucial to include the effects of environmental trends and stochastic variation in the environment in the development of sustainable harvest strategies (May et al. 1978; Lande, Engen \& Saether 1995; Brander 2007). The question of whether harvesting amplifies the effects of environmental changes on the variability in population size over time and increases extinction risk (hereafter called "harvest-interaction hypothesis") or alternatively, stabilizes population dynamics has been an unsolved problem for some years. During the last fifteen years, the question of potential interactions between climate and harvest has received growing interest in marine ecology, mainly due to the collapse of commercially important fisheries (Hutchings \& Myers 1994; 
Myers, Hutchings \& Barrowman 1997). Here, we assess whether harvesting can amplify environmentally-induced population fluctuations and affect dynamics of exploited populations in the changing environments in both marine and terrestrial ecosystems.

Our objective was to assess the ecological consequences of harvesting in a variable environment by identifying the mechanisms causing fishing/hunting to increase environmentally-induced population fluctuations in terms of changes in population size over time. Here, we review theoretical and empirical studies based on observational or experimental approaches that have evaluated the harvest-interaction hypothesis of higher variability in exploited population sizes over time. Based on our findings, we propose new avenues of research for understanding the effects of harvest on exploited populations of marine and terrestrial organisms.

\section{2 | HARVEST EFFECTS ON AGE/SIZE STRUCTURE}

Harvesting can be proportional (or balanced) on all age/size classes in a population.

However, removal of individuals through harvesting is rarely random with respect to size or demographic classes (Kuparinen \& Festa-Bianchet 2017). If the oldest and largest individuals are preferentially removed, or if harvesting pressure is high, the proportion of old individuals in the populations decreases. In exploited populations of northern cod Gadus morhua, the age structure contained 18 age classes in the 1960s, but the older fish disappeared and the age structure was truncated to 9 age classes more recently (Drinkwater 2002). The northern cod is not an exception: age truncation is pervasive in exploited populations where the proportion of individuals in the oldest age classes drastically decreases at a severe rate (reviewed by Barnett et al. 2017 for 63 exploited populations of fish). A growing body of empirical evidence shows that fishing plays a key role in changes in size structure, and that climate changes such as increasing water temperature contribute to a less extent to the observed changes in size 
distribution (Tu, Chen \& Hsieh 2018). Size-selective harvest is problematic because the oldest individuals may have different fecundity and survival rates that buffer the population against environmental changes. In fish, large/old females are generally more fertile than small/young ones and spawn during different temporal and spatial windows (Berkeley, Chapman \& Sogard 2004), hence spreading the risk of losing all the offspring when conditions are unfavorable. In ungulates, selective harvest can also lead to age truncation with a larger proportion of individuals in younger age-classes than populations not subject to hunting. Many studies have documented that in long-lived species, young individuals exhibit more variable survival rates over years than adults, adult survival being canalized and thus buffered against environmental variation (Gaillard \& Yoccoz 2003), a process called "demographic buffering” (Morris \& Doak 2004). Consequently, harvest-induced changes in age structure might increase sensitivity of the population dynamics to climate variation if the remaining age classes are more sensitive to climate variation. Conversely, one can expect dampened environmentallyinduced population fluctuations if harvest targets young individuals that are the most sensitive to climate variation. Harvest strategies are often designed to target specific demographic 104 classes. In many European ungulates, harvest quotas are designed to take more calves and 105 yearlings with low reproductive value (Apollonio, Andersen \& Putman 2010). In fisheries management, evidence is also accumulating that regulations stipulating a maximum size of

107 fish that can be harvested and thus favoring the removal of the youngest/smallest individuals 108 can reduce the negative effects of harvest (Birkeland \& Dayton 2005). Selective harvest 109 directed towards some specific age classes implies that hunters can identify the age of the 110 individuals. Group composition, phenotypic traits or coat color can be used to identify age 111 classes. For example, in wild boar (Sus scrofa), a social group is led by an old female, 112 followed by juveniles striped until 4 months of age and wearing a reddish coat until 6 months 
113 of age (Gamelon et al. 2012), making age determination straightforward. In fish, gill nets are

114 commonly used tools to select and remove individuals of specific size-classes.

115 A growing body of empirical evidence shows that age truncation might enhance climate

116 sensitivity and generate fluctuations in population size over years (Anderson et al. 2008). In

117 2012, from long-term data of 6 fish species, Rouyer et al. (2012) showed that high mortality

118 due to fishing is associated with a change in age structure that enhances the population

119 susceptibility to extrinsic environmental forcing (table 1). Five years later, Shelton and

120 Mangel (2011) confirmed through modeling and demographic data collected from the

121 literature including 45 fish species (table 1) that age-selective fishing increases the relative

122 contribution of recruits and thus amplifies the destabilizing effect of climate variation. This

123 finding has been further discussed by Sugihara et al. (2011). Recently, Cameron et al. (2016)

124 experimentally tested the hypothesis of enhanced fluctuations in population size when

125 adult/old individuals were removed using a terrestrial species, the soil mite (Sancassania

126 berlese). The experiment consisted of different harvesting treatments under different regimes

127 of environmental fluctuations. The authors showed that harvesting adults increased population

128 variability but only in variable environments. In a constant environment, harvest had no effect

129 on the coefficient of variation (CV) of population sizes over time. The laboratory study

130 provided experimental evidence that harvesting directed towards adults can increase climatic

131 sensitivity of exploited populations (table 1). Harvest may also select for accelerated life

132 histories with higher fecundity, early maturity and short lifespan (Anderson et al. 2008;

133 Allendorf \& Hard 2009; Kuparinen \& Festa-Bianchet 2017). When the rate of turnover of

134 individuals is accelerated, a population is moved towards the fast end of the continuum of life

135 history variation (see Gaillard et al. 2016) and becomes more prone to greater fluctuations in

136 population sizes in response to variation in environmental conditions (Gamelon et al. 2014).

137 In particular, environmental fluctuations generate temporal autocorrelations among fecundity, 
138

139

140

141

142

143

144

145

146

147

survival and other demographic rates that in turn influence both the mean and the variance of population size (Engen et al. 2013). The effects of temporal autocorrelation on the demography depend on life history variation: species with fast life histories are more sensitive to autocorrelation than slow species with opposite characteristics (Paniw, Ozgul \& SalgueroGómez 2018). A shift towards younger age classes due to harvest that accelerates the pace of life may thus also favour autocorrelation in population dynamics. Thus, it may be difficult to disentangle whether changes in population size are caused by harvest or changes in climate conditions, which in turn may increase the risk for overexploitation and population collapse.

\section{3 | HARVEST EFFECTS ON SPATIAL DISTRIBUTION}

The distributional range of some exploited species may shift in response to climate change (Mysterud \& Sæther 2010). For example, cod and pollock (Gadus chalcogrammus) distributions have changed over the last years in the northern oceans (Hollowed \& Sundby 2014). Northbound shifts in spatial distribution allow individuals to better cope with changing environmental conditions. Harvesting per se may affect the spatial distribution of exploited species (Takashina \& Mougi 2015). For instance, in a network of patches with and without harvest, individuals can move from patches without harvest to harvested patches, a process called compensatory immigration (see Gervasi et al. 2015 for an example on wolverines Gulo Gulo). Alternatively, when exposed to harvest, individuals might move to new habitats and exploit any available niche to avoid mortality risk (see Lefebvre et al. 2017 for an example on greater snow goose Anser caerulescens). Displacement can result in high spatial aggregation, or enhanced spatial heterogeneity of animal distribution (see Ciannelli et al. 2013 for a review on fish). Similarly, different age classes can inhabit contrasting habitats according to their age-specific needs, mobile abilities and competitive advantages (Rijnsdorp \& Pastoors 1995; Nøttestad et al. 1999; Fauchald, Mauritzen \& Gjøsaeter 2006; Breau, Cunjak \& Bremset 
2007), resulting in homogeneous populations in terms of spatial structure capable of

164 occupying various habitats. Harvest-induced changes in (st)age structure can also alter spatial structure and favour heterogeneity (Kuo et al. 2016). Empirical work has shown that such a constriction of geographic distributions associated with harvest pressure can weaken the populations' ability to buffer the effects of unfavorable environmental conditions (Planque $e t$ al. 2010). Populations become more vulnerable to climate variability, and fluctuations in population numbers and risk of local extinction increase (Hsieh et al. 2008; Kuo et al. 2016). If the goal of managers is to decrease population sizes, for instance to control overabundant populations of geese, increasing vulnerability to climate variability and local extinction risks might be a desirable outcome. Similarly, migration is a simple way to buffer climate-driven variations in terrestrial and marine ecosystems. Seasonal migration is a widespread phenomenon in vertebrates, being observed in fish, birds and mammals (Milner-Gulland, Fryxell \& Sinclair 2011). Migration patterns can be culturally transmitted through social learning in both marine (Corten 2002) and terrestrial environments (Jesmer et al. 2018). Harvest of mature individuals may lead to a loss of transmission of migration knowledge to younger individuals, alter migration patterns and lead to greater sensitivity to climate change (Fryxell et al. 2010). Hence, harvesting can affect the spatial distribution of exploited species and shifts in distribution can be unfavourable when facing a changing climate (see Hsieh et al. 2010 for a review in fisheries).

Moving from the effects of harvesting on the spatial structure of a single population to populations structured in space, populations separated in space that exhibit correlated fluctuations in population size over years are theoretically more prone to extinction because local patches can go extinct without being rescued by immigration from other populations (Heino et al. 1997; Earn, Levin \& Rohani 2000; Engen 2007). One of the key insights that has been derived from spatial population models is that increased synchrony in population 
fluctuations over larger areas tends to reduce population size and increase the risk of extinction (Foley 1994; Engen, Lande \& Saether 2002). Recent theoretical analyses have shown that proportional harvest itself, where the annual yield is proportional to the population size, tends to induce spatial synchrony (Engen 2017; Engen, Cao \& Sæther 2018). Greater synchrony implies that spatially variation in harvest strategies including protected areas could

193 be a way of avoiding this effect. In fact, theoretical results have shown that adjusting the

194 harvesting rate according to local population fluctuations can result in reduced spatial scaling of the population synchrony. Spatio-temporal changes in the covariation of key environmental variables are expected due to changes in climate, which may provide a mechanism to counteract climate-induced changes in the dynamics of exploited species. For example, if the spatial scaling of the environmental noise is altered because of alteration of the climate regime, the proportion of juveniles included in the harvest will influence the spatial scaling of the distribution of abundance (Engen, Lee \& Sæther 2018). Growing empirical evidence in

201 fisheries indicates that synchronized harvest at a large spatial scale plays a key role in 202 affecting the degree of spatial synchrony in population fluctuations, providing support for 203 theoretical expectations. For instance, Frank et al. (2016) showed that the size of 22 204 populations of cod fluctuate synchronously in North Atlantic not solely due to climate but 205 also due to harvesting.

\section{4 | HARVEST EFFECTS ON DENSITY REGULATION}

Fluctuations in size of natural populations are driven by climate effects (Sæther et al.

209 2000; Coulson et al. 2001; Stenseth et al. 2003; Berryman \& Lima 2006) and also by density 210 dependence, involving a negative feedback of the population density on the population 211 growth rate (Royama 1992; Turchin 1995). Mechanisms can vary but include intraspecific 212 competition, social behavior and other factors. Importantly, climate effects can interact with 
213 density-dependent regulation of population dynamics (Turchin 1995; Stenseth et al. 2003;

214 Barbraud \& Weimerskirch 2003; Gamelon et al. 2017; Hansen et al. 2019). For example,

215 effects of climate on demographic rates and population size can be stronger at high density

216 than at low density because when climate conditions are bad, food resources are more limiting

217 if the population is at or above carrying capacity (see Gamelon et al. 2017 for a case study on

218 dippers Cinclus cinclus; see Hansen et al. 2019 for a case study on Svalbard reindeer Rangifer

219 tarandus). If the population is above carrying capacity, the remaining individuals in the

220 population after harvest might exhibit improved fecundity and survival via compensatory

221 density dependence (Bonenfant et al. 2009), being for instance more likely to colonize

222 habitats of better quality instead of occupying less optimal places (MacCall 1990; Marshall \&

223 Frank 1995). In contrast, reduced population sizes can be associated with lower demographic

224 performance for the remaining individuals via Allee effects such as higher risk of starvation

225 due to stress (reviewed by Courchamp, Berec \& Gascoigne 2008; Péron 2013). The interplay

226 between climate and density dependence (Gamelon et al. 2017; Hansen et al. 2019), and

227 between harvest and density dependence (Boyce, Sinclair \& White 1999; Sandercock et al.

228 2011) have been well studied, but an integrative approach to the combined effects of

229 harvesting and climate on density-regulated populations remains lacking. An integrated

230 approach is strongly needed because complex interactions between harvest, density

231 dependence and climate variation might arise. For instance, harvest might influence the way

232 in which a population responds to density dependence, make it more or less vulnerable to

233 climate variation, and thus might ultimately amplify or dampen fluctuations in population

234 sizes over time.

235 
Empirical evidence is accumulating in marine species of fish that harvesting might magnify environmentally-induced fluctuations in population sizes. In a pioneering study, Hsieh et al. (2006) compared the temporal variability of 13 exploited vs. 16 unexploited fish

240 populations living in a common environment and subject to the same environmental

241 fluctuations. From long-term data, they found that the CV of annual larval abundance was

242 lower in unexploited than in exploited populations and concluded that the addition of 243 mortality from fishing resulted in increased temporal variability of all species subject to 244 variable environments (table 1). In terrestrial species, some studies have shown that specific 245 harvesting strategies may increase fluctuations in population size and favor cyclicity, 246 accentuating the risk of population collapse when environmental conditions are harsh (Fryxell 247 et al. 2010). In a case study of black grouse (Tetrao tetrix), Jonzen et al. (2003) demonstrated 248 that harvesting can cause quasi-cyclic fluctuations when the harvest fraction was time249 dependent, thus reducing the ability of the population to recover when environmental 250 conditions are unsuitable. Similarly, Bunnefeld et al. (2011) used simulations to explore the 251 effects of selective harvest by sex and age on population cycles in red grouse (Lagopus 252 lagopus). In general, a threshold harvest strategy that involves immediate removal of all 253 individuals above a critical population size generates a large variance in annual yield (Sæther, 254 Engen \& Solberg 2001; Sæther et al. 2005) and large fluctuations in age distributions. Engen 255 et al. (1997) therefore proposed a proportional threshold strategy, in which only a fraction of 256 the excess individuals above a lower critical threshold is removed. Proportional threshold 257 involves a reduction of the threshold when harvest is allowed compared to a pure threshold 258 strategy. The modified strategy allows for an increase in the number of years harvesting is 259 permitted, which in turn generates less variability in the annual yield (Sæther, Engen \& 260 Solberg 2001; Aanes et al. 2002; Sæther et al. 2005). Thus, the strategy should make it easier 
to separate out climate-induced influences on the population dynamics and hence adjust the

262 harvest tactics accordingly.

\section{6 | EVIDENCE FOR HARVEST EFFECTS ON COMMUNITY DYNAMICS IN}

\section{SPACE}

Species live in communities with other species and can compete for limiting resources.

267 The harvest of one species may induce cascading effects on other species because it may

268 affect interspecific interactions and hence ecosystem processes leading to alternative stable

269 states (Barkai \& McQuaid 1988; Kirby, Beaugrand \& Lindley 2009; Selkoe et al. 2015;

270 Gårdmark et al. 2015). Surprisingly, a topic that to a large extent has been ignored is how

271 harvesting affects the fluctuations of population size of interacting species. Jarillo et al.

272 (2018) showed that proportional harvesting, in which the catches at each location are

273 proportional to the population size, tends to synchronize fluctuations in population size of

274 competing harvested species in space, and thus ultimately increases the probability of

275 extinction. However, if other harvesting strategies are applied, such as fixed quota strategy for

276 catches more concentrated in areas with high population sizes, the outcome can be opposite:

277 harvesting can reduce the synchrony of the species (Engen, Cao \& Sæther 2018) and thus the 278 risk of local extinction. However, fixed quota harvest strategies are generally not sustainable

279 on the long-run (Lande, Engen \& Saether 1995; Lande, Sæther \& Engen 1997). Thus,

280 different harvesting strategies can have contrasting effects on vulnerability of interacting

281 species over large geographical areas to changes in climate and cause spatial decoupling of

282 ecosystem structures. Interactions imply that harvest of a given species may affect the

283 dynamics of entire food webs, also affecting non-harvested species. The removal of species at

284 low-trophic levels affects the dynamics of upper-trophic levels and thus the entire community

285 (Smith et al. 2011). Similarly, when apex predators are removed from the ecosystem or when 
their dynamics are modified by trophic down-grading, the entire ecosystem can be

287 destabilized through trophic cascades, involving changes in the abundance of multiple

288 interacting species subsequently to the change in abundance of a single species (McCann

289 2012; Terborgh 2015). Cascades can modify the response of the entire community to

290 changing climate conditions (Estes et al. 2011). For instance, the removal of carnivores might

291 lead to high abundance in herbivores as ungulates, higher herbivory and lower frequency and

292 intensity of wildfires (Estes et al. 2011). In marine systems, overfishing of large-bodied fish

293 might reduce herbivory, increase levels of disease and prevent the recovery of corals after

294 cyclones (Hughes et al. 2003). In this later example, interactions among species are essential

295 to the resilience of the community (Loreau 2010), and when some species decline or are

296 removed from the system, interactions are broken and the ability of the entire community to

297 recover from disturbances such as changing climate conditions decreases. Understanding such

298 interactions has received an increasing interest in the recent years and multi-species

299 interactions are now included in models for sustainable harvest of exploited populations

300 (Leslie \& McLeod 2007; Persson, Van Leeuwen \& De Roos 2014). Ecosystem-based

301 approaches are crucial to gain a comprehensive understanding of harvest-induced effects at

302 the community level.

303

304

7 | CONCLUSIONS

Does harvesting increase environmentally-induced fluctuations in population size?

306 Among empiricists, this question has mainly been addressed by marine ecologists and

307 evidence for the "harvest-interaction hypothesis" is accumulating (table 1). The combined 308 effect of fishing and climate on population fluctuations in fish stocks has received increasing 309 interest in the recent years (Lindegren et al. 2013; Frank et al. 2016) and both theoretical and 310 empirical works have provided evidence that specific types of harvesting strategies might 
311 increase environmentally-induced fluctuations in population size and thus extinction risk. In 312 terrestrial environments, studies evaluating the "harvest-interaction hypothesis" have mainly

313 developed theoretical approaches to evaluate how contrasting harvesting strategies might

314 enhance or reduce environmentally-induced fluctuations in population size. Surprisingly, 315 empirical evidence is lacking. Few field experiments have been conducted and little is known 316 on the combined effect of hunting and climate on population fluctuations in terrestrial species.

317 Available studies have measured the relative contributions of climate, density dependence and 318 harvesting on the population growth rate fluctuations (Koons et al. 2015 for a study on 319 American bison Bison bison; López-Montoya, Moro \& Azorit 2017 for a study on red Cervus 320 elaphus hispanicus and fallow deer Dama dama) whereas other studies have evaluated the 321 effect of different harvesting strategies on population dynamics (McGowan 1975; Mentis \& 322 Bigalke 1985; Connelly et al. 2003; Gervasi et al. 2015). Other studies have compared the 323 dynamics of harvested vs. natural populations in similar environments (Palmer \& Bennett Jr 324 1963; Pedersen et al. 2004). Tests of how harvesting enhances or dampens environmentally325 induced fluctuations in population sizes by comparing the dynamics of harvested vs. natural 326 populations in similar environments have not yet been conducted. We strongly encourage 327 analyses of this question on a large range of species with contrasting life histories (slow 328 versus fast species), with contrasting abilities to face environmental fluctuations (mobile 329 versus resident species, ectotherms versus endotherms), at different trophic levels (carnivores 330 versus herbivores) by using some of the existing long-term field studies of exploited 331 populations. Long-term individual-based studies with capture-mark-recapture data and 332 population counts are available for many exploited bird and mammalian populations.

333 Analyses of time series of classified counts and harvest data can be complicated by hunting 334 regulations and hunter preferences and also by covariation between abundance and 335 regulations. As stated by Festa-Bianchet et al. (2017) "It remains unclear, therefore, whether 
the response of heavily hunted populations to changes in density, weather, and resource availability differs from that documented by long-term studies of unhunted populations." A

338 promising avenue of research is to explore how hunting and climate interact and evaluate

339 whether, like observed in marine species, hunting enhances environmentally-induced

340 fluctuations in population sizes for terrestrial exploited species. Both the theory and the data

341 are now available to address this question of major importance in ecology, management and

342 conservation in exploited avian and mammalian populations.

\section{ACKNOWLEDGEMENTS}

345 We thank Marco Festa-Bianchet, John Fryxell, one anonymous referee and the Editor for their

346 helpful comments on previous drafts of this paper. Our study was funded by the Research

347 Council of Norway as part of the Centre of Excellence-grant to CBD (SFF-III 223257/F50)

348 and to SUSTAIN (244647/E10).

\section{AUTHORS' CONTRIBUTIONS}

351 M.G. led the writing of the manuscript. B.K.S. and B.-E.S contributed to the drafts and gave 352 final approval for publication.

353

\section{DATA ACCESSIBILITY}

355 Data have not been archived because this article does not contain data. 
Table 1 - Case studies with evidence that harvesting enhances environmentally-induced fluctuations in population sizes.

\begin{tabular}{|c|c|c|c|c|}
\hline Species & Environment & Approach & $\begin{array}{l}\text { Evidence for effects of harvest on greater environmentally- } \\
\text { induced fluctuations in population sizes }\end{array}$ & Source \\
\hline 29 species & Marine & Observational & $\begin{array}{l}\text { "This well-documented mechanism [age truncation] suggests how fishing } \\
\text { can make populations more susceptible to extrinsic environmental forcing." }\end{array}$ & Hsieh et al. 2006 \\
\hline 6 species & Marine & Observational & $\begin{array}{l}\text { "Our results demonstrate that populations exhibiting a truncation of their } \\
\text { age structure were associated with shorter-term fluctuations in time series, } \\
\text { which suggests an increased sensitivity to the short-term changes in the } \\
\text { environment." }\end{array}$ & Rouyer et al. 2012 \\
\hline 45 species & Marine & Observational & $\begin{array}{l}\text { "In a variable environment, the addition of mortality from fishing leads to } \\
\text { increased temporal variability for all species examined." }\end{array}$ & Shelton and Mangel 2011 \\
\hline 1 species of acarid mite & Terrestrial & Experimental & $\begin{array}{l}\text { "Only when environmental variation and harvesting were combined did we } \\
\text { see strong evidence of magnified fluctuations in abundance." }\end{array}$ & Cameron et al. 2016 \\
\hline
\end{tabular}




\section{REFERENCES}

Aanes, S., Engen, S., Sæther, B.-E., Willebrand, T. \& Marcström, V. (2002) Sustainable harvesting strategies of illow Ptarmigan in a fluctuating environment. Ecological Applications, 12, 281-290.

Allendorf, F.W. \& Hard, J.J. (2009) Human-induced evolution caused by unnatural selection through harvest of wild animals. Proceedings of the National Academy of Sciences, 106, 9987-9994.

Anderson, C.N.K., Hsieh, C., Sandin, S.A., Hewitt, R., Hollowed, A., Beddington, J., May, R.M. \& Sugihara, G. (2008) Why fishing magnifies fluctuations in fish abundance. Nature, 452, 835-839.

Apollonio, M., Andersen, R. \& Putman, R. (2010) European ungulates and their management 21 st century

Barbraud, C. \& Weimerskirch, H. (2003) Climate and density shape population dynamics of a marine top predator. Proceedings of the Royal Society B: Biological Sciences, 270, 2111-2116.

Barkai, A. \& McQuaid, C. (1988) Predator-Prey Role Reversal in a Marine Benthic Ecosystem. Science, 242, 62-64.

Barnett, L.A.K., Branch, T.A., Ranasinghe, R.A. \& Essington, T.E. (2017) Old-growth fishes become scarce under fishing. Current Biology, 27, 2843-2848.e2.

Berkeley, S.A., Chapman, C. \& Sogard, S.M. (2004) Maternal age as a determinant of larval growth and survival in a marine fish, Sebastes melanops. Ecology, 85, 1258-1264.

Berryman, A. \& Lima, M. (2006) Deciphering the effects of climate on animal populations: diagnostic analysis provides new interpretation of Soay sheep dynamics. The American Naturalist, 168, 784-795.

Birkeland, C. \& Dayton, P.K. (2005) The importance in fishery management of leaving the big ones. Trends in Ecology \& Evolution, 20, 356-358.

Bonenfant, C., Gaillard, J., Coulson, T., Festa-Bianchet, M., Loison, A., Garel, M., Loe, L.E., Blanchard, P., Pettorelli, N., Owen-Smith, N., Du Toit, J. \& Duncan, P. (2009) Empirical evidence of density-dependence in populations of large herbivores. Advances in Ecological Research (ed H. Caswell), pp. 313-357. Academic Press.

Boyce, M.S., Sinclair, A.R.E. \& White, G.C. (1999) Seasonal compensation of predation and harvesting. Oikos, 87, 419-426.

Brander, K.M. (2007) Global fish production and climate change. Proceedings of the National Academy of Sciences of the United States of America, 104, 19709-19714.

Breau, C., Cunjak, R.A. \& Bremset, G. (2007) Age-specific aggregation of wild juvenile Atlantic salmon Salmo salar at cool water sources during high temperature events. Journal of Fish Biology, 71, 1179-1191.

Bunnefeld, N., Reuman, D.C., Baines, D. \& Milner-Gulland, E.J. (2011) Impact of unintentional selective harvesting on the population dynamics of red grouse. The Journal of Animal Ecology, 80, 1258-1268.

Cameron, T.C., O’Sullivan, D., Reynolds, A., Hicks, J.P., Piertney, S.B. \& Benton, T.G. (2016) Harvested populations are more variable only in more variable environments. Ecology and Evolution, 6, 4179-4191.

Ciannelli, L., Fisher, J.A.D., Skern-Mauritzen, M., Hunsicker, M.E., Hidalgo, M., Frank, K.T. \& Bailey, K.M. (2013) Theory, consequences and evidence of eroding population spatial structure in harvested marine fishes: a review. Marine Ecology Progress Series, 480, 227-243. 
Connelly, J.W., Reese, K.P., Garton, E.O. \& Commons-Kemner, M.L. (2003) Response of greater sage-grouse Centrocercus urophasianus populations to different levels of exploitation in Idaho, USA. Wildlife Biology, 9, 335-340.

Corten, A. (2002) The role of conservatism in herring migrations. Reviews in Fish Biology and Fisheries, 11, 339-361.

Coulson, T., Catchpole, E.A., Albon, S.D., Morgan, B.J.T., Pemberton, J.M., Clutton-Brock, T.H., Crawley, M.J. \& Grenfell, B.T. (2001) Age, sex, density, winter weather, and population crashes in Soay sheep. Science, 292, 1528-1531.

Courchamp, F., Berec, L. \& Gascoigne, J. (2008) Allee Effects in Ecology and Conservation. OUP Oxford, Oxford; New York.

Drinkwater, K. (2002) A review of the role of climate variability in the decline of northern cod. Fisheries in a changing climate, American Fisheries Society, pp. 113129. N.A. McGinn, Bethesda, Maryland.

Earn, D.J.D., Levin, S.A. \& Rohani, P. (2000) Coherence and Conservation. Science, 290, 1360-1364.

Engen, S. (2007) Stochastic growth and extinction in a spatial geometric Brownian population model with migration and correlated noise. Mathematical Biosciences, 209, 240-255.

Engen, S. (2017) Spatial synchrony and harvesting in fluctuating populations: relaxing the small noise assumption. Theoretical Population Biology, 116, 18-26.

Engen, S., Cao, F.J. \& Sæther, B.-E. (2018) The effect of harvesting on the spatial synchrony of population fluctuations. Theoretical Population Biology, 123, 28-34.

Engen, S., Lande, R. \& Sæther, B.-E. (1997) Harvesting strategies for fluctuating populations based on uncertain population estimates. Journal of Theoretical Biology, 186, 201212.

Engen, S., Lande, R. \& Saether, B.-E. (2002) The spatial scale of population fluctuations and quasi-extinction risk. The American Naturalist, 160, 439-451.

Engen, S., Lee, A.M. \& Sæther, B.-E. (2018) Spatial distribution and optimal harvesting of an age-structured population in a fluctuating environment. Mathematical Biosciences, 296, 36-44.

Engen, S., Sæther, B.-E., Armitage, K.B., Blumstein, D.T., Clutton-Brock, T.H., Dobson, F.S., Festa-Bianchet, M., Oli, M.K. \& Ozgul, A. (2013) Estimating the effect of temporally autocorrelated environments on the demography of density-independent age-structured populations. Methods in Ecology and Evolution, 4, 573-584.

Estes, J.A., Terborgh, J., Brashares, J.S., Power, M.E., Berger, J., Bond, W.J., Carpenter, S.R., Essington, T.E., Holt, R.D., Jackson, J.B.C., Marquis, R.J., Oksanen, L., Oksanen, T., Paine, R.T., Pikitch, E.K., Ripple, W.J., Sandin, S.A., Scheffer, M., Schoener, T.W., Shurin, J.B., Sinclair, A.R.E., Soulé, M.E., Virtanen, R. \& Wardle, D.A. (2011) Trophic downgrading of planet Earth. Science, 333, 301-306.

Fauchald, P., Mauritzen, M. \& Gjøsaeter, H. (2006) Density-dependent migratory waves in the marine pelagic ecosystem. Ecology, 87, 2915-2924.

Festa-Bianchet, M., Douhard, M., Gaillard, J.-M. \& Pelletier, F. (2017) Successes and challenges of long-term field studies of marked ungulates. Journal of Mammalogy, 98, 612-620.

Foley, P. (1994) Predicting Extinction Times from Environmental Stochasticity and Carrying Capacity. Conservation Biology, 8, 124-137.

Frank, K.T., Petrie, B., Leggett, W.C. \& Boyce, D.G. (2016) Large scale, synchronous variability of marine fish populations driven by commercial exploitation. Proceedings of the National Academy of Sciences, 113, 8248-8253. 
Fryxell, J.M., Packer, C., McCann, K., Solberg, E.J. \& Sæther, B.-E. (2010) Resource management cycles and the sustainability of harvested wildlife populations. Science, 328, 903-906.

Gaillard, J.-M., Festa-Bianchet, M. \& Yoccoz, N.G. (1998) Population dynamics of large herbivores: variable recruitment with constant adult survival. Trends in Ecology \& Evolution, 13, 58-63.

Gaillard, J.-M., Lemaître, J.-F., Berger, V., Bonenfant, C., Devillard, S., Douhard, M., Gamelon, M., Plard, F. \& Lebreton, J.-D. (2016) Axes of variation in life histories. Encyclopedia of Evolutionary Biology, Elsevier, pp. 312-323. R. M. Kliman, Oxford, UK.

Gaillard, J.-M. \& Yoccoz, N.G. (2003) Temporal variation in survival of mammals: a case of environmental canalization? Ecology, 84, 3294-3306.

Gamelon, M., Gaillard, J.-M., Servanty, S., Gimenez, O., Toïgo, C., Baubet, E., Klein, F. \& Lebreton, J.-D. (2012) Making use of harvest information to examine alternative management scenarios: a body weight-structured model for wild boar. Journal of Applied Ecology, 49, 833-841.

Gamelon, M., Gimenez, O., Baubet, E., Coulson, T., Tuljapurkar, S. \& Gaillard, J.-M. (2014) Influence of life-history tactics on transient dynamics: a comparative analysis across mammalian populations. The American Naturalist, 184, 673-683.

Gamelon, M., Grøtan, V., Nilsson, A.L.K., Engen, S., Hurrell, J.W., Jerstad, K., Phillips, A.S., Røstad, O.W., Slagsvold, T., Walseng, B., Stenseth, N.C. \& Sæther, B.-E. (2017) Interactions between demography and environmental effects are important determinants of population dynamics. Science Advances, 3, e1602298.

Gårdmark, A., Casini, M., Huss, M., Leeuwen, A. van, Hjelm, J., Persson, L. \& de Roos, A.M. (2015) Regime shifts in exploited marine food webs: detecting mechanisms underlying alternative stable states using size-structured community dynamics theory. Phil. Trans. R. Soc. B, 370, 20130262.

Gervasi, V., Brøseth, H., Nilsen, E.B., Ellegren, H., Flagstad, Ø. \& Linnell, J.D.C. (2015) Compensatory immigration counteracts contrasting conservation strategies of wolverines (Gulo gulo) within Scandinavia. Biological Conservation, 191, 632-639.

Hansen, B.B., Gamelon, M., Albon, S.D., Lee, A.M., Stien, A., Irvine, R.J., Sæther, B.-E., Loe, L.E., Ropstad, E., Veiberg, V. \& Grøtan, V. (2019) More frequent extreme climate events stabilize reindeer population dynamics. Nature Communications, 10:1616.

Heino, M., Kaitala, V., Ranta, E. \& Lindström, J. (1997) Synchronous dynamics and rates of extinction in spatially structured populations. Proceedings of the Royal Society of London B: Biological Sciences, 264, 481-486.

Hollowed, A.B. \& Sundby, S. (2014) Change is coming to the northern oceans. Science, 344, 1084-1085.

Hsieh, C., Reiss, C.S., Hewitt, R.P. \& Sugihara, G. (2008) Spatial analysis shows that fishing enhances the climatic sensitivity of marine fishes. Canadian Journal of Fisheries and Aquatic Sciences, 65, 947-961.

Hsieh, C., Reiss, C.S., Hunter, J.R., Beddington, J.R., May, R.M. \& Sugihara, G. (2006) Fishing elevates variability in the abundance of exploited species. Nature, 443, 859862.

Hsieh, C., Yamauchi, A., Nakazawa, T. \& Wang, W.-F. (2010) Fishing effects on age and spatial structures undermine population stability of fishes. Aquatic Sciences, 72, 165178.

Hughes, T.P., Baird, A.H., Bellwood, D.R., Card, M., Connolly, S.R., Folke, C., Grosberg, R., Hoegh-Guldberg, O., Jackson, J.B.C., Kleypas, J., Lough, J.M., Marshall, P., 
Nyström, M., Palumbi, S.R., Pandolfi, J.M., Rosen, B. \& Roughgarden, J. (2003) Climate Change, Human Impacts, and the Resilience of Coral Reefs. Science, 301, 929-933.

Hutchings, J.A. \& Myers, R.A. (1994) What can be learned from the collapse of a renewable resource? Atlantic cod, Gadus morhua, of Newfoundland and Labrador. Canadian Journal of Fisheries and Aquatic Sciences, 51, 2126-2146.

Jarillo, J., Sæther, B.-E., Engen, S. \& Cao, F.J. (2018) Spatial scales of population synchrony of two competing species: effects of harvesting and strength of competition. Oikos, 127, 1459-1470.

Jenouvrier, S. (2013) Impacts of climate change on avian populations. Global Change Biology, 19, 2036-2057.

Jenouvrier, S., Desprez, M., Fay, R., Barbraud, C., Weimerskirch, H., Delord, K. \& Caswell, H. (2018) Climate change and functional traits affect population dynamics of a longlived seabird. Journal of Animal Ecology, 87, 906-920.

Jesmer, B.R., Merkle, J.A., Goheen, J.R., Aikens, E.O., Beck, J.L., Courtemanch, A.B., Hurley, M.A., McWhirter, D.E., Miyasaki, H.M., Monteith, K.L. \& Kauffman, M.J. (2018) Is ungulate migration culturally transmitted? Evidence of social learning from translocated animals. Science, 361, 1023-1025.

Jonzen, N., Ranta, E., Lundberg, P., Kaitala, V. \& Lindén, H. (2003) Harvesting-induced population fluctuations? Wildlife Biology, 9, 59-65.

Kirby, R.R., Beaugrand, G. \& Lindley, J.A. (2009) Synergistic Effects of Climate and Fishing in a Marine Ecosystem. Ecosystems, 12, 548-561.

Koons, D.N., Colchero, F., Hersey, K. \& Gimenez, O. (2015) Disentangling the effects of climate, density dependence, and harvest on an iconic large herbivore's population dynamics. Ecological Applications, 25, 956-967.

Kuo, T.-C., Mandal, S., Yamauchi, A. \& Hsieh, C. (2016) Life history traits and exploitation affect the spatial mean-variance relationship in fish abundance. Ecology, 97, 12511259.

Kuparinen, A. \& Festa-Bianchet, M. (2017) Harvest-induced evolution: insights from aquatic and terrestrial systems. Philosophical Transactions of the Royal Society B: Biological Sciences, 372, 20160036.

Lande, R., Engen, S. \& Saether, B.-E. (1995) Optimal harvesting of fluctuating populations with a risk of extinction. The American Naturalist, 145, 728-745.

Lande, R., Engen, S. \& Saether, B.-E. (2003) Stochastic Population Dynamics in Ecology and Conservation. Oxford University Press, Oxford; New York.

Lande, R., Sæther, B.-E. \& Engen, S. (1997) Threshold Harvesting for Sustainability of Fluctuating Resources. Ecology, 78, 1341-1350.

Lefebvre, J., Gauthier, G., Giroux, J.-F., Reed, A., Reed, E.T. \& Bélanger, L. (2017) The greater snow goose Anser caerulescens atlanticus: Managing an overabundant population. Ambio, 46, 262-274.

Leslie, H.M. \& McLeod, K.L. (2007) Confronting the challenges of implementing marine ecosystem-based management. Frontiers in Ecology and the Environment, 5, 540548.

Lindegren, M., Checkley, D.M., Rouyer, T., MacCall, A.D. \& Stenseth, N.C. (2013) Climate, fishing, and fluctuations of sardine and anchovy in the California Current. Proceedings of the National Academy of Sciences, 110, 13672-13677.

López-Montoya, A.J., Moro, J.G.M. \& Azorit, C. (2017) Drivers of population growth variations for two Mediterranean sympatric Deer. Ecological Research, 32, 703-712.

Loreau, M. (2010) From Populations to Ecosystems: Theoretical Foundations for a New Ecological Synthesis (MPB-46). Princeton University Press. 
MacCall, A.D. (1990) Dynamic Geography of Marine Fish Populations. University of Washington Press, Seattle, Washington.

Marshall, C.T. \& Frank, K.T. (1995) Density-dependent habitat selection by juvenile haddock (Melanogrammus aeglefinus) on the southwestern Scotian Shelf. Canadian Journal of Fisheries and Aquatic Sciences, 52, 1007-1017.

May, R.M., Beddington, J.R., Horwood, J.W. \& Shepherd, J.G. (1978) Exploiting natural populations in an uncertain world. Mathematical Biosciences, 42, 219-252.

McCann, K. (2012) Food Webs. Princeton University Press.

McGowan, J.D. (1975) Effect of autumn and spring hunting on ptarmigan population trends. The Journal of Wildlife Management, 39, 491-495.

Mentis, R.C. \& Bigalke, M.T.\&. (1985) Experimental hunting of grassland francolins in the Natal Drakensberg. South African Journal of Wildlife Research, 15, 12-16.

Milner-Gulland, E.J., Fryxell, J.M. \& Sinclair, A.R.E. (2011) Animal Migration: A Synthesis. Oxford University Press, Oxford, New York.

Morris, W.F. \& Doak, D.F. (2004) Buffering of life histories against environmental stochasticity: accounting for a spurious correlation between the variabilities of vital rates and their contributions to fitness. The American Naturalist, 163, 579-590.

Myers, R.A., Hutchings, J.A. \& Barrowman, N.J. (1997) Why do fish stocks collapse? The example of cod in Atlantic Canada. Ecological Applications, 7, 91-106.

Mysterud, A. \& Sæther, B.E. (2010) Climate change and implications for the future distribution and management of ungulates in Europe. Ungulate management in Europe: problems and practices, 349-375.

Nøttestad, L., Holst, J.C., Giske, J. \& Huse, G. (1999) A length-based hypothesis for feeding migrations in pelagic fish. Canadian Journal of Fisheries and Aquatic Sciences, 56, $26-34$.

Palmer, W.L. \& Bennett Jr, C.L. (1963) Relation of season length to hunting harvest of ruffed grouse. The Journal of Wildlife Management, 634-639.

Paniw, M., Ozgul, A. \& Salguero-Gómez, R. (2018) Interactive life-history traits predict sensitivity of plants and animals to temporal autocorrelation. Ecology Letters, 21, 275-286.

Pedersen, H.C., Steen, H., Kastdalen, L., Brøseth, H., Ims, R.A., Svendsen, W. \& Yoccoz, N.G. (2004) Weak compensation of harvest despite strong density-dependent growth in willow ptarmigan. Proceedings. Biological Sciences, 271, 381-385.

Péron, G. (2013) Compensation and additivity of anthropogenic mortality: life-history effects and review of methods. Journal of Animal Ecology, 82, 408-417.

Persson, L., Van Leeuwen, A. \& De Roos, A.M. (2014) The ecological foundation for ecosystem-based management of fisheries: mechanistic linkages between the individual-, population-, and community-level dynamics. ICES Journal of Marine Science, 71, 2268-2280.

Planque, B., Fromentin, J.-M., Cury, P., Drinkwater, K.F., Jennings, S., Perry, R.I. \& Kifani, S. (2010) How does fishing alter marine populations and ecosystems sensitivity to climate? Journal of Marine Systems, 79, 403-417.

Post, E., Langvatn, R., Forchhammer, M.C. \& Stenseth, N.Chr. (1999) Environmental variation shapes sexual dimorphism in red deer. Proceedings of the National Academy of Sciences of the United States of America, 96, 4467-4471.

Rijnsdorp, A.D. \& Pastoors, M.A. (1995) Modelling the spatial dynamics and fisheries of North Sea plaice (Pleuronectes platessa L.) based on tagging data. ICES Journal of Marine Science, 52, 963-980. 
Rouyer, T., Sadykov, A., Ohlberger, J. \& Stenseth, N.C. (2012) Does increasing mortality change the response of fish populations to environmental fluctuations? Ecology Letters, 15, 658-665.

Royama, T. (1992) Analytical Population Dynamics. Springer Science \& Business Media. Sæther, B.-E. (1997) Environmental stochasticity and population dynamics of large herbivores: a search for mechanisms. Trends in Ecology \& Evolution, 12, 143-149.

Sæther, B.-E., Engen, S., Persson, J., Brøseth, H., Landa, A. \& Willebrand, T. (2005) Management strategies for the wolverine in Scandinavia. The Journal of Wildlife Management, 69, 1001-1014.

Sæther, B.-E., Engen, S. \& Solberg, E.J. (2001) Optimal harvest of age-structured populations of moose Alces alces in a fluctuating environment. Wildlife Biology, 7, 171-179.

Sæther, B.-E., Grøtan, V., Engen, S., Coulson, T., Grant, P.R., Visser, M.E., Brommer, J.E., Grant, B.R., Gustafsson, L., Hatchwell, B.J., Jerstad, K., Karell, P., Pietiäinen, H., Roulin, A., Røstad, O.W. \& Weimerskirch, H. (2016) Demographic routes to variability and regulation in bird populations. Nature Communications, 7, 12001.

Sæther, B.-E., Tufto, J., Engen, S., Jerstad, K., Røstad, O.W. \& Skåtan, J.E. (2000) Population dynamical consequences of climate change for a small temperate songbird. Science, 287, 854-856.

Sandercock, B.K., Nilsen, E.B., Brøseth, H. \& Pedersen, H.C. (2011) Is hunting mortality additive or compensatory to natural mortality? Effects of experimental harvest on the survival and cause-specific mortality of willow ptarmigan. Journal of Animal Ecology, 80, 244-258.

Selkoe, K.A., Blenckner, T., Caldwell, M.R., Crowder, L.B., Erickson, A.L., Essington, T.E., Estes, J.A., Fujita, R.M., Halpern, B.S., Hunsicker, M.E., Kappel, C.V., Kelly, R.P., Kittinger, J.N., Levin, P.S., Lynham, J.M., Mach, M.E., Martone, R.G., Mease, L.A., Salomon, A.K., Samhouri, J.F., Scarborough, C., Stier, A.C., White, C. \& Zedler, J. (2015) Principles for managing marine ecosystems prone to tipping points. Ecosystem Health and Sustainability, 1, 1-18.

Shelton, A.O. \& Mangel, M. (2011) Fluctuations of fish populations and the magnifying effects of fishing. Proceedings of the National Academy of Sciences of the United States of America, 108, 7075-7080.

Smith, A.D.M., Brown, C.J., Bulman, C.M., Fulton, E.A., Johnson, P., Kaplan, I.C., LozanoMontes, H., Mackinson, S., Marzloff, M., Shannon, L.J., Shin, Y.-J. \& Tam, J. (2011) Impacts of Fishing Low-Trophic Level Species on Marine Ecosystems. Science, 333, 1147-1150.

Stenseth, N.C., Viljugrein, H., Saitoh, T., Hansen, T.F., Kittilsen, M.O., Bølviken, E. \& Glöckner, F. (2003) Seasonality, density dependence, and population cycles in Hokkaido voles. Proceedings of the National Academy of Sciences, 100, 1147811483.

Sugihara, G., Beddington, J., Hsieh, C., Deyle, E., Fogarty, M., Glaser, S.M., Hewitt, R., Hollowed, A., May, R.M., Munch, S.B., Perretti, C., Rosenberg, A.A., Sandin, S. \& Ye, H. (2011) Are exploited fish populations stable? Proceedings of the National Academy of Sciences, 108, E1224-E1225.

Takashina, N. \& Mougi, A. (2015) Maximum sustainable yields from a spatially-explicit harvest model. Journal of Theoretical Biology, 383, 87-92.

Terborgh, J.W. (2015) Toward a trophic theory of species diversity. Proceedings of the National Academy of Sciences, 112, 11415-11422.

Tu, C.-Y., Chen, K.-T. \& Hsieh, C. (2018) Fishing and temperature effects on the size structure of exploited fish stocks. Scientific Reports, 8, 7132. 
Turchin, P. (1995) Population regulation: old arguments and a new synthesis. Population 651 Dynamics, Academic Press, pp. 19-40. N. Cappucino \& P.W. Price, New York. 